\title{
Patrons and Their Work
}

As Buddhists the Thai assume a cosmos of nearly perfect justice. Those who break its moral laws are punished; those who contribute toward its scheme of justice are rewarded. The legal process moves steadily without benefit of published grievance, rules of evidence, or right of appeal. Sometimes impersonal nature is said to reach out and execute judgment by allowing one man to find a treasure while afflicting another with disease. More often judgment is said to be carried out by one of the countless beings that inhabit the cosmos. These beings, humans among them, stand somewhere in a hierarchy of power and impersonal wisdom. The higher ones in this hierarchy, having overcome selfishness, have risen through successive rebirths to positions where they may wield power over those below them. Low beings, such as animals, are relatively powerless and can be controlled by humans, who with their knowledge of traps, nets, and weapons can subdue even ferocious tigers. In turn humans are controlled by other humans, higher spiritual beings, and gods, who because of merit have achieved positions of power. Misuse of power and wisdom will inevitably result in their diminution or loss, either in this life or in another, after rebirth at a lower level. As beings strive upward or fall back, through their own actions increasing or decreasing their store of merit, there is merit mobility for all except those few who have escaped by achieving Nirvana.

Control of others suggests force or threat, but higher beings rarely work in such a manner. Because of their selflessness, they act compassionately toward beings beneath them, as a mother soothes her injured child without thought of her own wound. The child, in turn, is free to accept or reject its mother's attentions, but in rejecting 
them, it must accept the consequences, perhaps that help will not come so readily on another occasion. The Lord Buddha gave man knowledge of the moral law of the universe. Man stands free to reject it and be reborn as man or animal, or to accept the knowledge and decrease his suffering by rebirth as a superior being. So higher beings, with their greater selflessness, compassion, and wisdom, aid lower beings.

The familiar patrons and their clients of this world are segments of this cosmic hierarchy. They extend from slave to king, each entrusted to perform his duty as client to those above him, and in turn as patron to those below him. As patron a man compassionately gives benefits to his clients in return for their gratefully rendered services. Should he fail to give them their benefits, he stands in danger of losing them; should his benefits be great, he will never want for aid. As client, each must reciprocate, but if duties are performed in a slovenly manner, these benefits disappear. The lonely beggar with outstretched hand has alienated some patron and is suffering the consequences. The dutiful client, on the other hand, is richly rewarded (Hanks 1962).

History recounts the work of patrons. According to the Chronicles of the North, settlement of Thai people began in the northern part of present Thailand when the patron god Indra desired to instruct the people in the precepts of Buddhism. He sent Visu Kamma, disguised as what may be a kind of deer, to the kingdom of his client Phrayā Korani, whose men pursued it through many adventures until they founded a city (Notton 1926, 1:1-10). Similarly, by looking to the patrons of Bang Chan we may observe the benefits they brought to this area. Some of these lesser human patrons we have already met: Uncle Sin, who gave the temple; Chyn the martinet, who protected his fellow hamlet residents and the temple; and Kamnan Phlym, benefactor of his hamlet and commune. Bang Chan's patrons include human, demihuman, and spiritual beings.

\section{Human Patrons}

Mari was helped by his patrons to raise himself from trader to landlord. He could trace his father's and his father's father's line back to Pattani, where they were captured by a general of Rama III and brought as spoils of war to Bangkok. Like the slaves of the Bunnags, 
these people were settled on Sāen Sāeb canal under a patron (LMH 12/9/53). Born after 1868, the date set by Rama $V$ for the children of slaves to be born free, Mari was never a slave. We know nothing of his life until he asked for a particular woman in marriage; her father had remained in the Bang Chan area dauntlessly guarding the property of the Bunnags and the surao of Allah. Mari took the hennastained hand of his bride and moved to live conveniently near his work in Minburī. There he purchased fish and garden produce for sale in the Bangkok markets. When padi became the important produce of the region, he bought a larger boat, the better to handle the bigger cargoes. In 1914, at about the age of forty, he bought land in Bang Chan and profited from the increased prices by growing some padi himself as well as transporting it. The profits were converted into farmlands worked by renters or by his grown children. He became imam of the local surao congregation (LMH 8/3/57). By the time of his wife's death, about 1925, he had made a pilgrimage to Mecca and become owner of 500 rai of rice-producing land, with holdings scattered over several communes. These lands he gave to his children when he moved from Bang Chan to marry for a second time ( JRH 6/25/53).

Rama IV, who advocated free enterprise for his kingdom, would have been delighted to hear the tale of Mari's initiative. Despite his resemblance to self-made capitalists of the West, it can scarcely be argued that individual enterprise took place in any Western sense. We have seen that the important jobs in Bangkok had been cornered by Chinese artisans or skilled workers of other ethnic groups. The city's retail outlets were similarly controlled. In principle, the control operated like the land concessions of the nineteenth century. The owner of a market granted concessions to retailers eager for access to the buying public. Each retailer in turn granted concessions to a limited number of suppliers, such as Mari, who scoured the canals for chickens, betel, or whatever the countryside was producing. The supplier received a somewhat lower price than he might have obtained if he had peddled his wares from house to house. Yet in terms of the volume and stability of business, he was better off to spend his time hunting up wares for the insatiable market. Besides, a supplier considered himself a notch or two higher on the social scale than a peddler.

Access to these closed groups was gained through a series of 
introductions by one or more patrons. A young man fresh from the home of his parents might be lent a boat to begin operations. A supplier patron might allocate to this new client some of the farms where produce had customarily been bought. The rest he had to find for himself. Once arrived with his wares at a Bangkok market, he had to be introduced to the retailer by a patron. Instead of a market with free access, we find guildlike monopolies at each step. Self-made men are all but inconceivable in this scene. ${ }^{1}$

In the more glorious ascents to higher social levels the patrons appear distinctly in the foreground. Three grandnephews of Uncle Sin were growing up in the no-longer-new hamlet on Kred canal, the year about $1908 .^{2}$ Their father had prospered and become the owner of 120 rai of land, more than double his initial holdings. A widow of one of these grandnephews told the story she had heard:

My husband's father and mother knew an old Laotian priest named Āchan Thā at Chakra temple in Bangkok. When they wanted my husband's older brother to go to school, they sent him to live with this priest at the temple and go to school. At first he was a temple boy but later he became a novice and still later a priest at this same temple. He became well known as a preacher and used to be invited to give sermons in the palace. While he was still a novice at the temple, my husband was sent to join him. My husband became sick; so his mother brought him back in less than one year. He never continued his education, because their father died, and he had to help his mother raise rice. The next time he went away he went to join the cavalry for his two years of military service. Then he fell from his horse and injured his liver. This became a permanent injury all his life. [About 1915] my husband's younger brother was also sent for his education to Chakra temple, where he lived with his eldest brother. He stayed there many years but was a priest for only two years. This eldest brother, before his death, recommended him to the naval school and was able to support him while he was there. He became an of ficer in the Royal Navy, now has a place to live in Bangkok, and plenty of money. [LMH 9/22/53]

Of these three brothers, the eldest died a promising young priest. The second in effect never left Bang Chan, though he became a prosperous farmer. The third rose to high position as a naval officer. Though Buddhists would certainly comment on the varying store of merit enjoyed by these brothers, here we must underscore the patron's task. ${ }^{3}$ The old Laotian priest first made it possible for these brothers to enter the temple and secure their education; without aid of this kind, entry would have been very difficult if not impossible. ${ }^{4}$ In effect the parents transferred their children to the priest. They 
gave up the services rendered by all but one of their children in return for the priest's help in educating the others. Then when the eldest son was established, he became the patron for his youngest brother and could introduce him to the naval school. From the temple he moved to other patrons in the navy, who guided him further.

\section{The Lord of Life}

Besides these lesser patrons, Bang Chan experienced the benefits of a new patron during the first decades of the twentieth century. This was the king. To be sure, this figure with his awesome titlesLord of Life (Chao Chiwit), Lord of All the Earth (Phrachao Phaendin), and many others-had long been present on the scene. Yet he did not rule the people. Instead he was the benefactor of a few chosen people of the realm. From the king these royal clients received a monopoly of power over the people of certain provinces and a provincial city as seat of government. In gratitude they returned annual tribute, appeared at the capital to the royal summons, drank in ceremony the water of fidelity, and supplied the royal army with troops. They in turn farmed out monopolies of power to favorites who were the traditional equivalents of modern district officers. Each received from this patron an opportunity to grow rich from the wealth of food and labor at his disposal and forwarded a share to the patron. For his part the king provided for the defense of the realm, built temples to ensure its preservation, raised some of the resources he needed through trade or his special monopoly over the port of Bangkok, and dealt with foreigners. Only when the common people served at one or more of these tasks did he rule them. At best he ruled the people indirectly.

In theory a king could withhold these patents of power. Rama IV took over directly the care of his palace city. His famous edict commanding the people to cease throwing refuse in the canals was but one example of his personal interest in making Bangkok agreeable for foreign residents (Moffat 1961:30-31). He had simply decided to exercise the monopoly of power over the city himself. ${ }^{5}$

In the next reign, Rama $V$ began to take upon himself, bit by bit, the direct rule of his realm. Instead of granting his clients monopolies of power, they were to become his official arms, reaching to the farthest hamlet in the kingdom. Instead of granting his governors the 
right to live from the revenues they could collect, he paid them salaries to carry out his will. The transition to the new organizational form came to take greater time than its authors had hoped. Nevertheless, people such as the residents of Bang Chan, whose temple Rama $\mathrm{V}$ had named, did encounter the royal presence directly for the first time.

Like most of the Chakri sovereigns of the past, Rama $\mathrm{V}$ and his successor, Rama VI (1910-1925), had canals dug extensively. It had been discovered that waterways were not just avenues by which clients could escape into the wilderness, but access routes for new settlers. In the adjoining provinces beyond Bang Chan, royal engineers laid out and supervised the digging of canals through the plains. Some people left Bang Chan to take up these newly opened lands. In 1902 Rama V granted to a certain well-known Nāj Loet a charter for passenger service by steam launch to help move people and their goods to these remote spots. ${ }^{6}$ The extending of canals, however, involved complex hydraulic problems of level, volume, and flow. Nāj Loet's launches could not pass through parts of Sāen Saeb canal during the dry season because it had become filled with silt. In 1902 the royal engineers went to work dredging out a new channel (Min. Ag. 1957:69). Then farmers complained that the water level in the new canals was not high enough to flood their fields; they lost their rice crops (LMH 7/14/57). The royal patron responded by erecting a series of locks and gates to regulate the water level (Min. Ag. 1957:93; Ingram 1955:79-87).

Bang Chan farmers were grateful for the water controls provided by their patron. One of the residents of the new hamlet on Kred canal remembered: "The water gates helped make the water stay longer in the field. Before the water gates we plowed and planted in dry land, and when it rained, the rice would sprout. After this we could plow in wet soil and the rice sprouted right away. We could no longer thresh in the fields because the land was under water. So we moved to thresh on the house mound" (LMH 8/12/57). Traders such as Mari were also grateful for the water gates, for now the canals held enough water during the dry months to enable them to take their boatloads of padi to market.

The royal patron further assumed the task of maintaining order within the country. He withdrew this whole slice of sovereignty from the royal governors and turned over to them the narrower duty 
of enforcing his decrees. Graham, who witnessed the transition, commented:

A matter of scarcely less importance than the organization of the general administration was the provision of an adequate police force. With the timehonored custom of collusion between of ficials and professional criminals strong in the land, from which indeed many of the old chiefs [royal governors] derived considerable profit, it was scarcely to be expected that any genuine effort to suppress crime entirely would be made by the country justices of the old regime, even at the urgent command of the king. By creating a monopoly of this form of industry the chiefs no doubt exercised a sort of check, and restricted evil-doing to the ranks of their own dependents, for it was very noticeable that with the recognition of rural officialdom and the removal from the chiefs of their powers and authority, violent crime of every description increased to an alarming extent and very soon passed altogether beyond the control of the authorities. [Graham 1913:255-256]

These new salaried officials, some trained by European advisers, eschewed the granting of monopolies in crime. Their only recourse was force, but the assistant district officer ( palad amphoe) plus a few kamnans and hamlet headmen formed a pathetic group to cope with the problem. Accordingly, a countrywide police force was organized in 1906. Two years later police stations were erected in the provincial center at Minburi and in the district office of Bāngkapi. Yet for a while brigands continued to flourish in the area. A nearby resident described the scene: "S$\overline{a e n}$ Saeb canal was without many houses. At Bam Phen temple robbers were frequent. They fastened a rope high up across the canal to prevent the rice boats [with their tall masts and sails] from passing. The boatmen caught in the rope would have to come ashore, where the robbers threatened to kill them if they did not give up their money. The police were only at Bāngkapi and Minburī" (LMH 8/18/57). At Bang Chan the need for vigilance continued for a decade or more, and hamlets organized their own protection.

As the new police organization began to work, residents of Bang Chan sensed its effect first in the efforts to enforce the edict of Rama VI in the year of 1912 against gambling. Gambling had long been a holiday pleasure during the New Year celebrations, and even a monarch's voice was not powerful enough to stop it immediately (Lumbini 1925:180). A woman said: 
We have always played cards in this part of Bang Chan, even though we are nearer the police station [than those living farther north on Bang Chan's rivulet]. If the police came to arrest people, we would pay them or give them food and drink. . . . Some police wanted to play cards and made good money gambling. When such a policeman came along, he took off his hat and held it high on a pole to warn us he was coming, then we could see over the tall grass. People would stop and invite him to come in. Now police thirst less for money. They are trained well. They listen to sermons on every Priest's Day [Wan Phra]. If one of them thinks of money too much, he has to resign. [JRH 12/3/53]

Gradually the king's servants learned to keep his peace more effectively, and farmers of Bang Chan were grateful for another benefit from their patron.

Rama $\mathrm{V}$ had long espoused the value of education for his clients. A formal palace school for princes and selected children of officials was organized during the first years of his reign. He personally founded schools in Bangkok, dispatched many of his sons to European schools and universities, and with the aid of Prince Damrong made the first step toward universal education (Jumsai 1951:19-23). In 1899 the Buddhist priests throughout the kingdom were ordered to begin giving instruction to the young in the vicinity of their temples. Any man or boy who wished might join the classes and learn to read sacred scriptures in the vernacular.

Under the system administered by Prince Wachirayan the central government appointed priests as education and religious directors of the various administrative circles (monthon) or groups of provinces throughout the country; and these, province by province, established subelementary (mūnlasyksā) and elementary (prathom) schools in those village temples where one or more priests were willing and able to serve as teachers. The director for Bangkok Circle (Monthon Krungthēp), which covered the lower Chao Phrayā river area, including Bang Chan, moved briskly and in the first year established, he says, some 59 schools with 69 teachers and 1,544 pupils in four of the rural provinces. A Bang Chan Canal Temple School (Rongrian Wat Khlänng Bang Chan) is specifically reported to have been in operation in 1901, with one priest-teacher giving instruction at the mūnlasyksā level to thirty-six pupils. The new school is mentioned in 1902 but thereafter becomes lost in more general district and provincial statistics. This brief glimpse in old official reports suggests that Bang Chan promptly heeded the government order to establish a temple school and that it recruited a larger than average 
class of students (Thai National Archives, 5 S, 26/12, "Reports on [Ecclesiastical Affairs in] Monthon Krungthēp," Phra Thammatrailōkāchān, R.S. 119, R.S. 121, 1899/1900, 1902/03). Perhaps we can see here the energetic hands of leader Chyn, the new kamnan Phlym, or Uncle Sin.

The government provided encouragement but no financial support and little supervision for the new school in Bang Chan, which must have been conducted in an amateur, informal, and irregular manner, and probably sometimes not at all. An older man recalled:

When I was about eight, my parents sent me to the temple as a temple boy when my mother's younger brother was ordained. I was a lazy boy and did not want to learn. I just wanted to run away and stay home. Once I ran away but hid in the bushes near my parents' house because I was afraid they would punish me. When it was dark, my parents cried because they were afraid I was in trouble. Then I came out of the weeds and met them. They did not punish me but sent me back to the temple the next day. My parents wanted me to learn to read, but I liked to play around and have fun. I liked tattooing and also to work as a blacksmith, hammering out knives for sale. After living at the temple for four years I returned home. [LMH 3/1/54]

Only the more prosperous farmers could spare their children for any regular or extended schooling; the poor needed them to tend the buffalo and work in the padi fields. ${ }^{7}$ All would have sent their sons, if they could, to study sacred texts and thereby learn life's moral principles. ${ }^{8}$ By itself, literacy offered little of value to the farmer, who supported priests in part to provide literary services for him. But because sacred texts were important and contact with them was of value, the new schooling was considered an asset, and parents in Bang Chan were pleased with this benefit provided by their royal patron (Hanks 1959).

Bang Chan clients were also pleased with the new system of recorded land deeds, since it helped reduce friction between neighbors: "Once I had an argument with my neighbor. She was plowing in my land. We sent for Kamnan Phlym. He settled it by putting up land markers. He knew because of the title deed showing where the boundary lay" ( JRH 6/25/53). The clients of the royal patron were released from corvée but were expected to pay somewhat higher taxes in return. The poll tax inaugurated in 1896 varied between 1.5 and 6 baht according to the prosperity of the region (Ingram 1955:59). Land taxes increased and were calculated according to the yield of the field as well as whether or not the land was under 
cultivation (ibid.:77). Few found their tax burdens heavy at 1.25 baht per rai or less. ${ }^{9}$ The former palace workers alone still owed corvée service; they were ordered to be ready for summons at any time. Rama VI called infrequently on their services, and then permitted them to hire substitutes (LMH 2/6/54).

The days of freedom from public service were limited, for in 1904 a new edict called for national conscription for military service. The district offices were soon calling upon young men for examination and selection. In Bang Chan many young men resumed farm work on the day following their interviews. ${ }^{10} \mathrm{~A}$ few from each commune boarded one of Nāj Loet's steam launches for the army or police barracks. One man recalled, "At twenty-two [1920] I was drafted to be a policeman and worked at the police department in Bangkok for one year. I got top grade in the examination and so was moved to the station near the Jause bridge. When I got top grade on another examination, I got twenty baht a month as salary. After two years I left the service because my time was up. I came back to Bang Chan to work with my mother" ( JRH 10/23/53).

Some six of Bang Chan's young men were taken into the Royal Guards, that regiment where all received slightly higher pay and special uniforms for their part in state ceremonies (LMH 8/3/57). Despite urgings to remain in service as the date of severance approached, no one from Bang Chan remained beyond the minimum term. Severance was an anticipated relief; it was said in Bang Chan, "Soldiers are treated like slaves" ( JRH 10/1/53). Tales by returning conscripts did not dispel local apprehension; but even so, when they had a choice, village young men tended to choose the army rather than the despised police (LS 10/5/48).

In 1913 Rama VI publicly observed that he had reduced his clients' liability to corvée in order to afford them time to devote themselves "diligently to the pursuits of livelihood." Thus he felt justified in restricting access to firearms and drugs, and prohibited gambling on holidays "in order to avoid the propensity of people to waste their money" (Lumbini 1925:180). Besides urging industry on his clients, in 1918 he further declared, "In connection with the work of prospering the condition of the Siamese nation as befits a civilized people, I have ordered the Decree relating to the use of family names to come into force during this year ..." (ibid.:218).

Most of these edicts drifted over the heads of the country people, who took little notice. Bang Chan hardly honored the prohibition on 
gambling, as we have seen. Few owned firearms or used drugs. The farmers had never had family names but were willing enough to adopt them, if this would please their patron. District of ficials rendered aid to those who had difficulty thinking of one. Brothers usually honored their parents by taking the same name, but sometimes husbands took the names of their wives. Soon almost everyone had complied, yet for many years neighbors had to shout around to get the family name of the people next door. ${ }^{11}$ The more significant promulgations of the reign (the new laws and court procedures, the augmented postal system, the extension of the railway, even the Wild Tiger Corps) affected little these law-abiding illiterate paddlers of boats a few miles outside the capital.

\section{The Spirit Patrons}

Agriculture is a mechanical process, the stirring of soil, dropping of seeds, and gathering of the resulting crop. Yet more than this is needed to assure a Bang Chan farmer that he will have his crop in December or January. Fish, rats, and birds may spoil the harvest. A sudden November storm may flatten the grain. A buffalo may die the night before plowing. Any one of these events affects the harvest, and farmers are keenly aware of multiple contingencies beyond their control. This knowledge does not incline a man to select his seed less carefully or to decide that weeding is unimportant. Equally important, however, are the spirit patrons to whom he turns for help.

The king too once made offerings to the guardians of the realm through the royal plowing and other ceremonies that ensured good crops within the country (Wales 1931:228-237, 256-264). Farmers in Bang Chan still observe comparable rites on a smaller scale. The first plowing must be done on an auspicious day in May or June. A man brings flowers, incense, and candles, perhaps sweets, and places them in a corner of the field. Facing the direction of the naga, the serpent on whose back the cosmos rests, but who also, as a rainbow, provides the rain from heaven, he recites the following address:

Lord of the Place, Lord of the Land, Please protect the rice from insects.

Please make the rice grow well.

Mother Earth, Mother of Rivers,

Please protect the rice from all attacks.

[JRH 3/2/54] 
Then he prods the buffalo and plows three concentric furrows in a direction that smoothes the scales of the cosmic serpent (LS 11/4/48). A few weeks later, at the first sowing of rice, he again offers incense and petitions his spiritual patrons:

Lord of the Place, Lord of the Land, Mother Earth, Mother of Rivers, May you protect the Rice Mother from harm.

[JRH 3/2/54]

Those who uproot the padi shoots from the seed bed and transplant them into the fields also call upon these spirit protectors to guard the crop.

In November, as the padi kernels begin to form, a woman goes into the fields with offerings for the Rice Mother. This deity is so beautiful in her pregnancy that a man, carried away by her charm, would frighten her with his advances. Consequently it must be a woman who brings the sour-tasting fruits that pregnant women prefer and invokes her, saying:

Mother Rice, mother of splendor,

Mother with the beauteous hair,

Mother with starlike eyes,

Mother on a level with gods,

Mother of most feminine beauty,

Hail spirit of rice, come!

Stay wherever you wish in the fields.

Come and help the kernels grow,

Come into the granary in abundance, come.

[JRH 12/18/54]

As the first stalks of the new crop are cut, a farmer lights an incense stick and gives thanks. Once the crop is on the threshing floor, a woman for the last time goes out to the field. With a few gleanings and rice stalks she makes a little doll and invites the soul of the Rice Mother to enter the doll and be transported to the house. The doll ceremonially enters its special abode, the granary, as the first padi is moved from the threshing floor for storage. Again the Rice Mother's permission must be obtained before padi is removed from the granary, and then it must be taken out only on special days during the months with even numbers of days. When the crop is sold, the boatman, after loading his boat with padi, pauses and returns the 
spirit of rice to the house with wishes for an abundant harvest in the coming year. ${ }^{12}$

The work of spirit patrons extends far beyond these few concerned with agriculture. The Earth Guardian (Phra Phūm) watches over each house from his own little house in the northeast corner of the compound. He should be notified when the Rice Mother is coming to the house, just as he is notified of any other newcomer, be it an overnight guest or a newborn baby. The ancestral spirits ( $p h i$ $p \bar{u} j \bar{a} t \bar{a} \bar{j} \bar{a} j$ ) customarily receive offerings when a daughter of the house is married. ${ }^{13}$ When offended, they sometimes cause illness (Textor 1960:223-235). There are guardian spirits of various places, such as

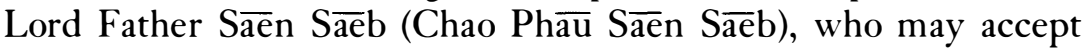
some special petition for help. These spirit patrons are numerous, their jurisdictions rather vaguely specified; when properly addressed (bon), they render unusual aid. ${ }^{14}$

In 1917, the year of the Little Snake, the waters rose and flooded the fields for a great distance. Farmers first brought their buffalo to higher ground on the house mounds. As the waters rose still higher, they moved the beasts to the house platforms. Fodder was gone. People scurried to rescue the store of last year's padi and shared it with the buffalo. Children fished from windows in their houses. A man made his fastest boat trip to Bangkok, right over the fields where the rice plants had drowned. When the waters receded, people counted their dead buffalo and looked into empty granaries. Women set off to earn money. The price of rice, already swollen by the demands of hungry people in war-torn Europe, rose to unprecedented heights. The royal patron rushed to help his clients, forsaken by their spirit patrons. In his birthday address Rama VI stated:

The government authorities have rendered every possible assistance within their power. They have helped to convey cattle to places of refuge on high ground, carried out various protective measures, attended to the farm animals afflicted with disease, and provided remunerative employment for destitute inhabitants. The Buddhist clergy has assisted by allowing the monasteries situated on high ground to be used as refuges for cattle, and the temples and other buildings therein as places for temporarily storing the grain belonging to the people affected by the floods.... [Lumbini 1925:208]

Through relief funds, grain was bought for distribution as food among the destitute and for seed among the farmers. They planted 
it, but almost everywhere it withered in the drought of the following season. Influenza and plague struck the nation (Lumbini 1925:220-221). The king sent his doctors to instruct the people in the prevention of disease and took steps to regulate the price of rice (ibid.:224).

If angered spirit guardians caused the damage, the particular protectors of Bang Chan were soothed enough to grant their clients special favors after the flood. The crop of 1918 was locally good; prices were high. Those who ordinarily fished for a living left their gear under their houses and rented land to grow rice. Prosperity reached this spot in the countryside: "I made money and got rich after the flood year. In the old days one kwian brought forty baht. The year after the flood one kwian brought one hundred sixty baht. Many Chinese came to buy the padi. The government was sending rice to foreign countries and was buying as much as it could. That year I was twenty years old, and everyone in the family was rich" (LMH 8/11/54). ${ }^{15}$

Farmers suddenly became heavy buyers. They had long bought their plowshares, yoking chains, and mattocks in the market. Sugar, coconuts, chili, and garlic had been luxuries to be bought only occasionally. Whenever floods had washed away the home gardens and orchards in other years, people had done without. But now with money jingling in their little bags they could buy salt fish and coconuts from the south and even have enough left over to replace worn clothing and implements. Up the side canals came a host of vendors eager to sell cupboards, tables, and teapots to these prospering ones (LMH 5/20/53, 2/22/54). In two or three years the old thatch and bamboo seemed less in keeping with their new wealth. Houses of sawed teak, the eaves capped with naga-like finials, rose along the canals to match the one of Kamnan Phlym.

Some farmers, fearful of losing their grain another year, sought to conserve their earnings:

When the children were grown and my brother and I could work in the fields, mother changed to buying and selling things. She did not want to use up the money we were earning and so kept buying more things to sell. She bought pots for cooking, coconuts, betel nut, and bananas. At that time people used sugar in a pot which cost one salyng. She bought these things in the stores along Saen Saeb canal in order to sell them later in Bang Chan. In the dry season the children would go with her to help carry things home. When the water in the canals was low, she could not go very far to sell. In 
this way the money from the crop was not used up; we could live from the profits of trade. [LMH 8/4/57]

In the wake of this prosperity the last bits of brush were cleared away. Owners, eager to gather in the profits for themselves, sent away their tenants. All hands turned to the fields. With an extra team of buffalo, a small household could work twenty or thirty rai, a large one as much as fifty. Those with still larger holdings invested in hired labor. Men from the northeast who a few years later would become pedicab drivers in Bangkok hired themselves out for the growing season at eighty to one hundred baht ( JRH 12/3/53). Poor relatives also came to join their wealthier kinsmen: "My parents lived on Sām Wā canal near Minburī. There were many of us, and we were very poor. We rented lands there. My father's younger sister and her husband asked my father to come and rent a field of fifty rai. I was seventeen or eighteen years old at the time, and we moved here two years after the flood of 1917" (LMH 9/22/53).

Pleased with such demonstrations of compassion toward those below them in the hierarchy, the spirit patrons lightened the work of the farmers. For several seasons Bang Chan watched as a tall tower began to grow across the fields near Minburi. One day in the year 1920 smoke began to ooze from its top. A steam mill had been built

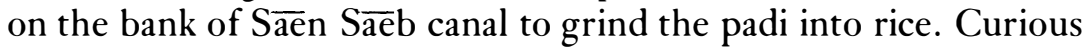
farmers paddled past the dusty wharf to watch grain boats loading and unloading. In a few more years many from Bang Chan brought their boats alongside these docks to have their own padi milled.

Bang Chan prospered for at least a decade. Its patrons had drawn people to settle on the land and extinguish the last claims of the wilderness. The weaverbirds disappeared; weeds and mosquitoes thinned out. A new Bang Chan was born.

\section{The Fruit of Their Work}

Bang Chan was hardly identifiable until the 1920s. The rivulet that acquired that name had drained the plains for centuries. The temple with the same name had been built on its banks a generation earlier. Perhaps the commune of Kamnan Phlym bore that name in the registry at the district office. Where the name came from no one knew. Most names of locations on the central plain suggest a landmark or some activity that occurred there, such as Marketville (Bāng Sȳ) or Bottleville (Bāng Khuad). Bang Chan means Village of the 
Rise, or the Steep Place, yet no resident ever pointed to any feature of the monotonous plain that would justify the name.

Before the 1920s local people saw as hamlets only the distant places where others dwelt. Like watching the blue of a lake melt at close range into green and gray, they regarded themselves as household dwellers. A woman described the scene: "From Sāen Sāeb canal I would go up Bang Chan canal to the mosque. Beyond this were some houses where the road bridge now stands. Then came the To Imam's house. Beyond were no more houses until the temple. Near the temple was my father's mound. Up Kred canal lived Sud; on Bang Chan canal was grandmother Faeng. Farther along was Nāng Pan. At the far end of Kred canal was Waud Kred [the local name for the hamlet on Kred canal, never used by its residents]" (LMH 8/3/ 57). Only in the more distant places did this observer begin to see the collective; nearby were just dwellings where known people lived. The Laotians alone had seen a collective identity when they named their hamlet Village of the Mound of Earthly Splendor. The rest were too unconcerned with any collective identity to wish to search out a collective name. ${ }^{16}$

As new settlers came and built their houses on the land they intended to plow, even the isolation that made hamlets identifiable until the 1920s disappeared. Boatmen passed no long, solitary stretches of brush along the banks. Houses formerly clustered now spread out as owners decided to work the whole of their lands by themselves. A uniformity of dwellings and fields emerged in the Bang Chan area.

The social communities bound together by the exchange of labor and services had begun to decline a dozen years before 1920. No one called all his neighbors to thresh the crop in the fields after 1908 because the water level was too high. Having cut the crop, the workers went home, and the owner's houseboat brought the sheaves of padi to the house mound by boat. There two or three buffalo barely had room to tread out the grain between stacks of straw and mounds of padi. Two or three people did the work formerly done by the hamlet. Machines for winnowing the threshed padi began to appear; one person cranked the blower while his helper fed the machine (LMH 8/18/57). As for milling, those who took their padi to the mill in Minburi and brought rice home no longer needed to call out the young people. The more enduring high water and the 
disappearance of tall grasses thinned the vegetation so that weeding too became a task for only a few people. A hamlet had no occasion to meet except on the days of harvest.

Since all sought to grow more padi, such labor-saving arrangements were heartily welcomed. All households worked to the limits of their capacity for their own advancement. They exchanged labor grudgingly, when possible hiring labor to speed the extra tilling and to process a larger crop ( $\mathrm{LMH} \mathrm{8/18/57).} \mathrm{Grown} \mathrm{children} \mathrm{at} \mathrm{home}$ were counted as blessings, and a family was reckoned as poor or wealthy according to its available working children (LS 12/31/48). Lacking these resources, a man ventured to exchange labor for a few of the more arduous tasks "only with special people" (LMH 2/8/ 54). ${ }^{17} \mathrm{~A}$ transformation was taking place in the padi field:

Formerly if we had no food, we could go to a neighbor's house to eat with them. It was easy to ask them for help. We could stay two or three days with them and eat chicken. We could borrow a buffalo for planting. Since there were fewer people, we could plant rice in another man's field without his paying attention. Now we must work every day to earn money. Even a banana leaf has value for sale. [LMH 11/31/53]

Like most people of Bang Chan when discussing the past, this old man spoke in a matter-of-fact tone.

Households turned to emphasizing their independence, selfsufficiency, and achievements:

My son's life is like mine. My son and daughter-in-law lived with me. I too lived with my parents after marriage [1915-1920]. Then when my other children were big enough to help he moved out. I gave my son a few rai of land to work and sell for himself. I also gave him a buffalo and plow; these are the instruments of his occupation. All the rice money came to me, just as it went to my father; and if I asked for money, my father gave it to me. When the money first came in, you could buy anything you liked: a house, food, or anything. I too was living in a thatch house next to my father's and built a big house which cost five hundred to six hundred baht. My son's house cost three thousand to four thousand baht. [JRH 1/29/54]

Fewer children chose to set off for new lands on the edge of the wilderness. Parents could hold them at home in the big teak houses built by Chinese carpenters (LMH 2/8/54). No longer busy at work bees, people staged tonsure ceremonies for their eleven- and thirteen-year-olds. ${ }^{18} \mathrm{~A}$ woman who grew up in the hamlet at Kred canal recalled the ordination of her son in the early 1920s: "We had a 


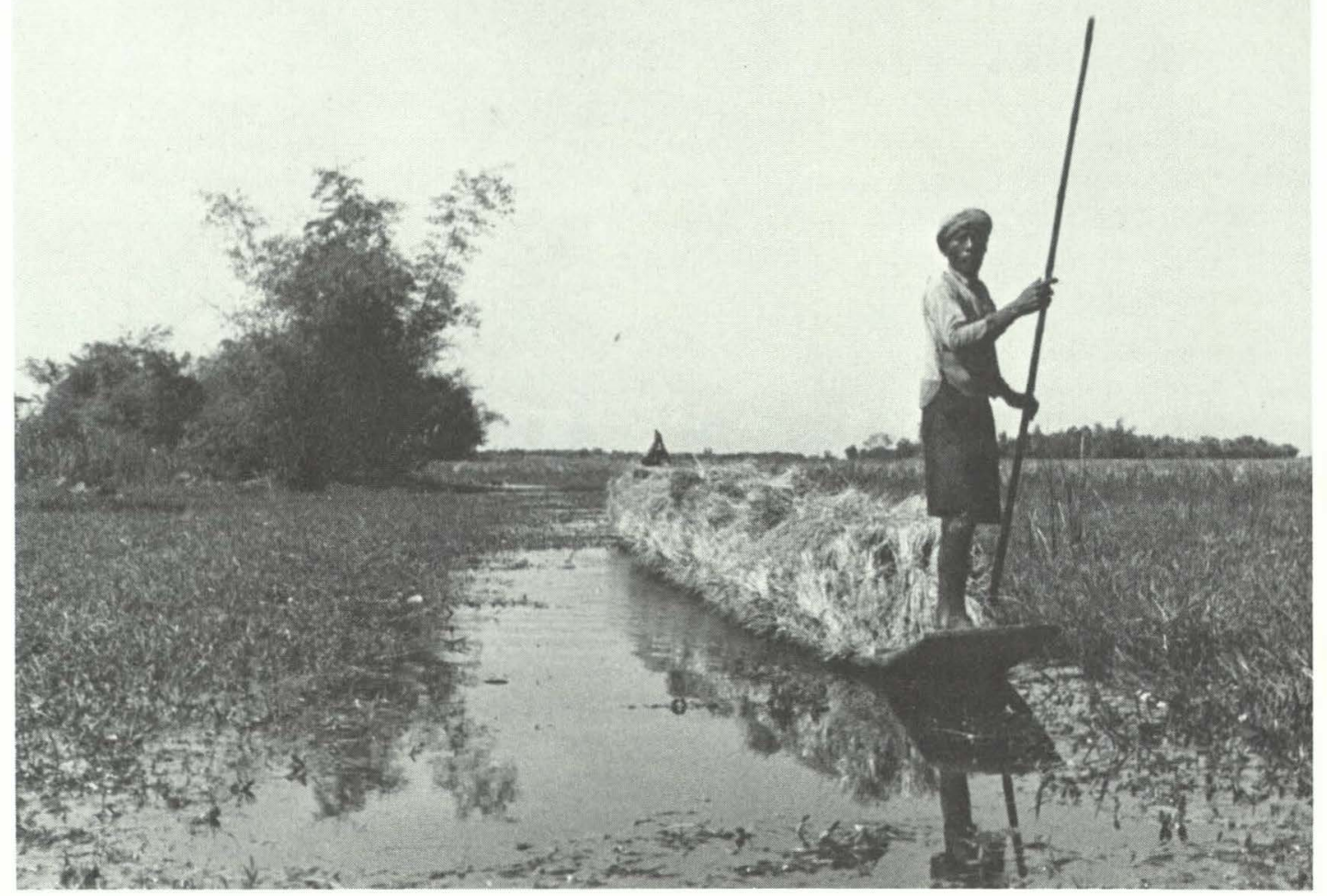

The harvest returns to the farmhouse

Photo by Lauriston Sharp

theatrical troupe playing for a day and a night. Altogether we paid nine hundred baht. ${ }^{19}$ It was not like today. People brought food, not money. When it was all over, there was food enough for another celebration" (LMH 8/13/57). Such celebrations demonstrated parental love for a child as well as a household's capacity for ostentatious spending and for attracting people from far and near.

Yet the younger generation had outgrown its tiny hamlets and roamed over the countryside. Young men were free to move about in the slack season: "When I was seventeen or eighteen [about 1920], I wanted to go to the gambling place on Saen Saeb canal which was open every Priest's Day [Wan Phra]. It was the day before priest's day [Wan Kon]. I was working at home with my parents but did not have any money. I decided to steal some padi. So I told my mother I 


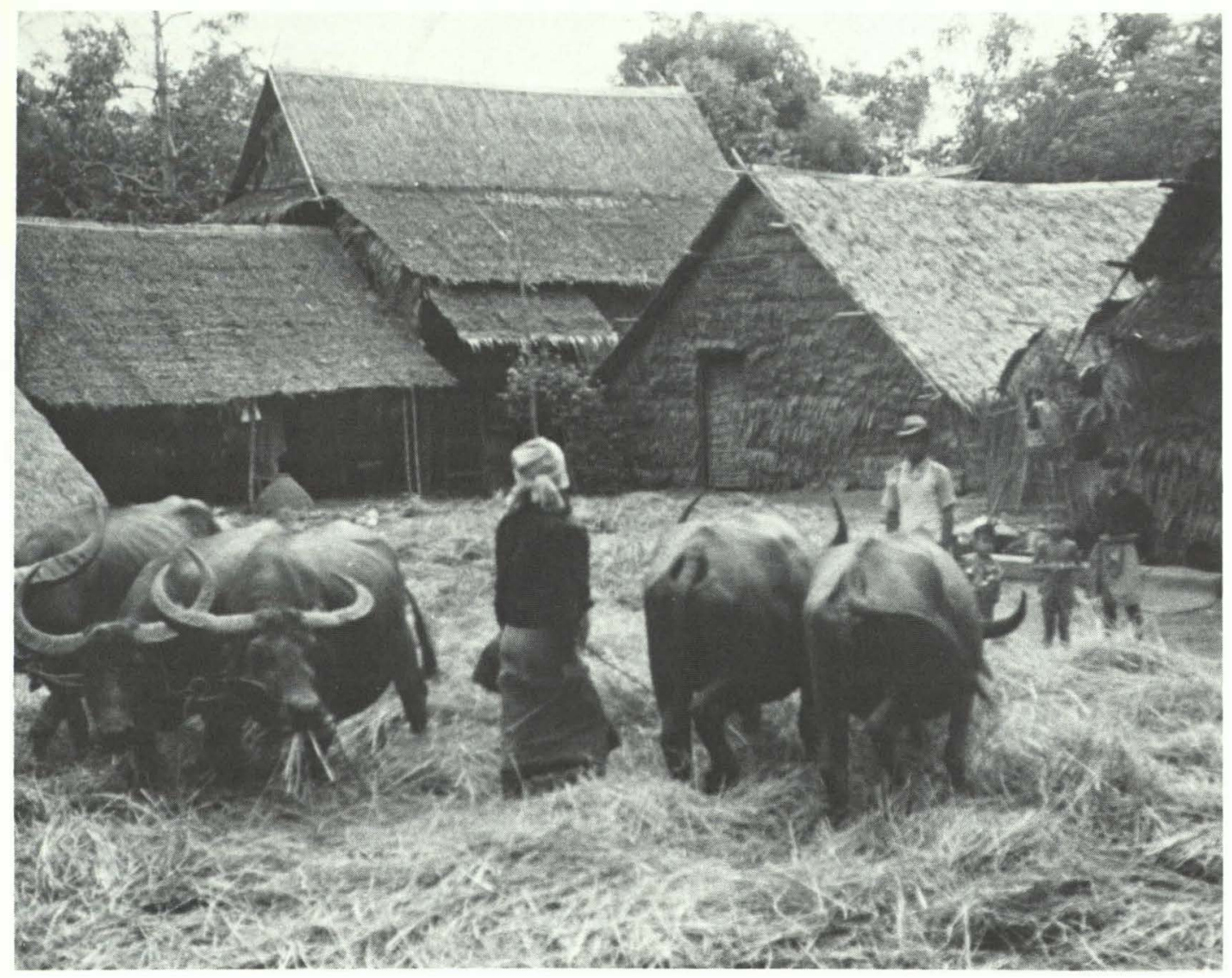

The threshing

Photo by Lauriston Sharp

wanted to go back to the house from the fields. I stole two thang of padi and sent it with Cham to be sold. So I got baht for gambling the next day" (LMH 3/1/54).

About the same period six young men from five scattered locations within Bang Chan formed themselves into a gang of rogues (naklēng). They met as friends for drinking and attended ordination ceremonies as a group. (One of these young men decided a few years later to organize a theatrical troupe $(l i k \bar{e})$ :

After getting married I decided to learn acting. I went to Bangkok after harvest to learn because I had some relatives who were actors. When I came back, I became head of a theatrical group. There were thirteen people in all. We played "Khun Chang Khun Phaen," and "Phrām Kae Saun" or "Laksanawong." My neighbor's boy Chom was a child announcer who had 
to speak like an Indian. We played in many places as far away as Chachoengsao and Nakāun Nāyok. The most we made was eighty baht for playing all day and all night long. The least we earned was thirty-five baht. [LMH 11/31/53] ${ }^{20}$

A broad field of movement had burst upon the young.

While hamlets dissolved into households or neighborhoods and youth moved into a larger world, Bang Chan was born. It lacked geographical boundaries, for farmers had settled in the interstices between it and its neighbors, just as they had settled between the hamlets. Administrative lines crisscrossed here and there. People knew they lived in the administrative hamlet (mūbān) of headman Liam or Tuj in the commune of Kamnan Saung or Suk in the district of Bāngkapi or Minburī. For all the effect these boundaries had in making a social community, residents might as well have been told their latitude and longitude.

Bang Chan had a center, the temple. Aside from its religious functions, it served at first as no more than a landmark for directing strangers. The tower of the reliquary built by Phra Samutmo loomed across the padi fields like a beacon. Subsequent merit makers embellished the temple grounds with memorials $(c h \bar{e} d \bar{l})$, boatlanding shelters, bridges, and sacred images. People of the area came with food for the priests, and brought their sons for ordination and their dead for cremation. Just as the market square with its fountain served as a pivot for many a European village, so Bang Chan's temple came to be thought of as the community's center. There the people came for boat races; there the temple fair was held, and the annual round of rites.

It offered only the barest political focus. The head priest, with his lay manager and corps of assistants, was scarcely a patron comparable to Kamnan Phlym. He might summon the strength of the surrounding householders to dig a pond for the priests, but only those pious ones who felt that they must gain merit came to dig for a few days; the less concerned occupied themselves elsewhere and sensed no loss of benefits. Some head priests demanded greater piety by refusing to permit fishing near the temple, so as to prevent the taking of life. Others left with the people the initiative in making merit. Still the head priest was a patron of sorts. Certainly everyone respected him, for he was learned and must have had more than the 
average store of merit to have achieved such a position. He could attract the services of the most important men of the area. And the destitute came and received a portion of the food given to the priests. During a flood the temple mound offered haven for buffalo and kept stores of grain dry. One had but to ask the head priest when to begin plowing and in what direction, and he looked it up in his book. Each year the priests chanted for an abundant, but not too abundant, rain (Wells 1960:89-95). Priests from the temple blessed new houses, placated the ghosts of the recently dead, and offered their medicine and rituals for curing the sick. They could not loan money on a parcel of land or prevent theft of buffalo, but still, here were constant patrons for all afflicted by existence. One magnificent kamnan appeared but then disappeared; the temple continued, its organized chapter of priests the only perdurable corporate entity in the social life of the community.

Gradually Bang Chan became something of an identity around this center. Bang Chan was a presence, but one did nothing in its name. A group of men might cut the weeds in the canal to make passage easier for boats, but this they did at the request of the temple manager or the head priest for the temple fair. A man built a wooden house for his wife and children but never to beautify Bang Chan. The young man on his way to a rendezvous spoke of leaving and returning to Bang Chan, but no known point precisely marked the place of his departure or return. The community became most tangible when he was away from it, perhaps in talking with farmers from other localities while waiting at the dock of the rice mill. He lived in Bang Chan while others lived on Sām Wā canal or at Lōlae. In speaking to them he sometimes referred to "Bang Chan people" (chāw Bang Chan).

We have but to contrast this shadowy identity with the concreteness of the former hamlets under a patron. The hamlet's existence depended on the benefits given by the lord, even in his absence, and the services returned by the inhabitants. They, slaves and freemen, lived there at his bidding; by following his wishes they could live. When needs arose, he satisfied them. Kamnan Phlym also gave his hamlet firm identity. When clients disputed the ownership of land or sought money, they came to him. Indeed, they had moved to or remained at his hamlet because of him. 
Without such a patron a community was shapeless. To be sure, the king was Bang Chan's patron, but the patron of all the people is the patron of none. His officials were only remote figures. Their impersonal duties-suppression of crimes, organization of work on canals, land surveys-were appreciated benefits, but they brought the officials little nearer to the farmers. Loaning money to a client, paying his debt, or speaking to a landlord on his behalf exceeded their office. Besides, as salaried officials, they often lacked the resources necessary for an office of this kind. ${ }^{21}$ On the local scene the salaryless hamlet headman without private wealth could serve no more competently. Kamnan Phlym was an anachronism from the past who resembled the old rural leaders, the chao myang (see Graham 1913:251-254). As long as he collected taxes, received his share of them, and lived in the community, he could minister to popular needs in a personal fashion, and serve as a local rallying point. His successor, shorn of these powers, perhaps lacking wealth and receiving only a salary, could not replace him. Without the patron there was no community, no collective existence that was recognizable. ${ }^{22}$

Bang Chan had never enjoyed so many patrons. The benefits proffered were greater than had ever been received. Household heads had never cared more lavishly for their clients. Rice buyers from the mill had never offered higher prices. Public peace had never been so well kept as by the district officer with his aides in the police. The king tended to the souls of his subjects more effectively by providing schools for their sons. The Rice Mother and Lords of the Place and Land had filled the granaries to unprecedented fullness. Each desire was met by some one of these many patrons; as an assemblage with shadowy identity Bang Chan flourished. The day was coming, however, when distress would force Bang Chan to seek other patrons for help. 